\title{
Production of the major soluble antigen of Renibacterium salmoninarum in Escherichia coli K12
}

\author{
Thomas H. Grayson, Andrew J. Evenden, Martyn L. Gilpin, Colin B. Munn* \\ University of Plymouth, Department of Biological Sciences, Plymouth PL4 8AA, United Kingdom
}

\begin{abstract}
A DNA fragment containing all but the first 90 base pairs of gene msa encoding p57, the major soluble antigen of Renibacterium salmoninarum, was cloned in the plasmid vector pUC18 and subsequently a soluble fusion protein was produced using the pMAL expression vector system. The fusion protein retained major epitopes shared with the native p57 molecule and provided a source of protein suitable for further immunological analysis which was independent of in vitro cultures of this slow growing organism. Antiserum raised against the purified fusion protein was used to probe Western blots of cell extracts and extracellular products derived from $R$. salmoninarum cultured in vitro. The results show that under conditions of iron-restriction, both the production and processing of p57 are reduced.
\end{abstract}

KEY WORDS: Renibacterium salmoninarum - Bacterial kidney disease $\mathrm{BKD} \cdot$ Major soluble antigen

Bacterial kidney disease (BKD) is a chronic, granulomatous disease affecting farmed and wild salmonid fish worldwide (Evelyn 1993). The causative agent of BKD, Renibacterium salmoninarum, is a Gram-positive, slow growing, fastidious, intracellular pathogen which is difficult to culture in vitro. Cultures of the bacterium may take at least 6 to $8 \mathrm{wk}$ and are prone to contamination. This is probably the major reason why little is known about the virulence or pathogenicity of the organism (Evenden et al. 1993).

Considerable attention has been devoted to the major soluble antigen, the predominant cell surface and extracellular protein (ECP) which has been associated with hydrophobicity and virulence (Bruno 1988, 1990). This protein, also referred to as hemagglutinin (Daly \& Stevenson 1987) and p57 (Weins \& Kaattari 1991), has an apparent molecular mass of 57 kilodaltons $(\mathrm{kDa})$ and is produced in considerable quantities by Renibacterium salmoninarum within the tissues

\footnotetext{
- Addressee for correspondence
}

and sera of infected fish (Turaga et al. 1987). Certain characteristics of p57, such as hydrophobic and leukoagglutinating properties (Weins \& Kaattari 1991) and acidic isoelectric point (pI 4.5 to 4.8 ) are reminiscent of other bacterial adhesins (Dubreuil et al. 1990). In addition, p57 possesses potent immunosuppressive properties which are rapidly lost with the proteolytic degradation of the protein (Rockey et al. 1991). Recent studies have demonstrated that the proteolytic degradation of p57 generates most, if not all, of the immunoreactive components of $R$. salmoninarum ECP and p57 may possess an autoproteolytic activity (Griffiths \& Lynch 1991). The $\mathrm{N}$-terminal sequence of $\mathrm{p} 57$ has been determined and gene msa encoding this protein has now been cloned and sequenced (Chien et al. 1992). The aim of this study was to generate a source of recombinant p57 protein in order to remove the timeconsuming dependence upon in vitro cultures of $R$. salmoninarum. In addition, antibodies raised against the recombinant protein were used to probe Western blots of cell extracts and ECP from $R$. salmoninarum cultured in vitro and under iron-restricted conditions.

Materials and methods. Escherichia coli strains JM109 and XL1-Blue were used as host strains for plasmid vectors pUC18, pMAL-c and pMAL-p (New England Biolabs) and were cultured in Luria-Bertani medium at either 22 or $37^{\circ} \mathrm{C}$. When appropriate, $100 \mu \mathrm{g} \mathrm{ml}^{-1}$ of ampicillin and $0.2 \%$ glucose were added to the medium. Isolates of Renibacterium salmoninarum including MT444 and the type strain (ATCC 33209) were cultured in Mueller-Hinton medium supplemented with $0.1 \%$ L-cysteine hydrochloride (MHCB) at $15^{\circ} \mathrm{C}$ and the availability of iron was restricted in cultures of $R$. salmoninarum by the addition of ethylenediamine di(o-hydroxyphenylacetic acid) (EDDHA) as previously described (Grayson et al. 1995).

From the sequence available for Renibacterium salmoninarum gene msa (Chien et al. 1992) 2 restriction 
sites close to the initiation codon were identified as suitable for the construction of translational fusions using the pMAL system for the production of maltosebinding protein (MBP) fusions (New England BioLabs): Hpal located at nucleotide 180 and Stul located at nucleotide 228 . The HpaI truncated gene would encode a product of 513 amino acids and 49795 molecular weight, whilst the Stul truncated gene would encode 497 amino acids of 47613 molecular weight. Both of these truncated proteins would include the major epitopes of p57 (Chien et al. 1992). It was decided to directionally clone either a $1.88 \mathrm{~kb} \mathrm{HpaI/Sall}$ fragment or a $1.65 \mathrm{~kb}$ Stul/Xbal fragment which had been excised from PMLG57 and ligated into the polylinker in order to enable the production of almost full length $\mathrm{p} 57$ fused to the carboxy-terminus of MBP (molecular mass $42.7 \mathrm{kDa}$ ).

Cultures of Escherichia coli XL1-Blue containing fusion plasmids were induced with IPTG at either 22 or $37^{\circ} \mathrm{C}$ and samples were removed over a time course for analysis. All of the following steps were carried out either on ice or at $4^{\circ} \mathrm{C}$ to minimise protein degradation. For affinity purification, at $2 \mathrm{~h}$ post-induction, a sample was harvested and resuspended in column buffer (20 mM Tris- $\mathrm{HCl}, 200 \mathrm{mM} \mathrm{NaCl}, 1 \mathrm{mM}$ EDTA, $1 \mathrm{mM}$ $\mathrm{NaN}_{3}, 1 \mathrm{mM}$ PMSF; pH 7.4). The sample was freezethawed, sonicated, centrifuged and the supernatant (crude extract) removed and retained. The pellet was resuspended in column buffer and retained as a suspension of insoluble material. An aliquot of amylose resin was washed with column buffer and mixed with an cqual volume of crude extract. The resin pellets were washed twice with column buffer, then resuspended in SDS-PAGE buffer. For the production of larger quantities of MBP-p57 fusion protein cultures of E. coli XL1-Blue containing the fusion plasmid were grown at $37^{\circ} \mathrm{C}$ and cells were induced with IPTG for $3 \mathrm{~h}$ at $37^{\circ} \mathrm{C}$. Affinity purified MBP-p57 fusion protein was obtained by using an amylose resin column. The diluted crude extract containing MBP-p57 fusion protein stored on ice was loaded onto the column and subsequently, the column was washed free of all protein other than the specifically bound MBP fusion protein. MBP-p57 was eluted with column buffer containing $10 \mathrm{mM}$ maltose. Protein concentrations were estimated (Bradford 1976) and yields of up to $50 \mu \mathrm{g} \mathrm{ml}^{-1}$ of culture were obtained

Wistar rats were immunized subcutaneously with $100 \mu \mathrm{g}$ of affinity-purified MBP-p57 fusion protein emulsified in Freund's complete adjuvant (FCA), and then boosted $3 \mathrm{wk}$ later with $100 \mu \mathrm{g}$ of protein emulsified in Freund's incomplete adjuvant (FIA). Control sera were gathered prior to immunisation. Rabbit antiMBP antiserum was obtained from New England BioLabs Ltd. Immunoblot analyses of clones producing either p57 or MBP-p57 fusion protein and of Renibac- terium salmoninarum cell Iysates and culture supernatants were performed using the electrophoretic transfer procedure (Towbin et al. 1979) following SDSPAGE in the presence of $5 \% \beta$-mercaptoethanol (Laemmli 1970). Blots were probed with primary antibodies and specific binding was detected by immunoperoxidase staining of horseradish peroxidase-labelled swine anti-rabbit immunoglobulins or rabbit anti-rat IgG (Dako). The preparation of $R$. salmoninarum cell lysates and extracellular products which were used in immunoblot analyses has been described (Grayson et al. 1995)

Results and discussion. Using Renibacterium salmoninarum strain MT444 DNA a genomic library was constructed in the ECoRI site of pUC18, using Escherichia coli host strain JM109. Clones were picked from master plates from which duplicate plates had been immunologically screened with rabbit antisera raised against $R$. salmoninarum ECP using nitrocellulose filter discs. The phenotype was checked by probing Western blots with rabbit anti- $R$. salmoninarum ECP (Fig. 1) which demonstrated the presence of several strongly immunoreactive bands of molecular masses from about 20 to $58 \mathrm{kDa}$. The plasmid isolated from this clone was designated pMLG57 (Fig. 2). Further characterisation including restriction mapping and DNA sequencing confirmed that pMLG57 contained a 1.9 kilobase $(\mathrm{kb})$ EcoR1 fragment of $R$. salmoninarum DNA which possessed all but the first 90 base pairs (bp) (30 amino acids) of gene msa fused in-frame with and under the control of the lac promoter.

Recombinant plasmids, designated either pMC57HS or pMP57SX, were isolated which contained the msa gene inserted in-frame with malE as either a $1.88 \mathrm{~kb}$ Hpal/Sall fragment or a $1.65 \mathrm{~kb}$ Stul/Xbal fragment in either the pMAL-c (6145 bp) or pMAL-p (6220 bp) vectors, respectively (Fig. 3). The production of MBP-p57, either within the cytoplasm (pMC57HS) or following export to the periplasmic space (pMP57SX) of Escherichia coli XL1-Blue, was accompanied by considerable
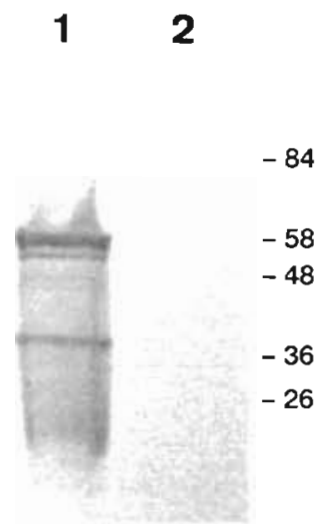

Fig. 1 Western blot of immunopositive clone isolated from a pUC18 ECoR1 gene bank using host strain Escherichia coli JM109 probed with rabbit antiRenibacterium salmoninarum ECP. Track 1: E. coli expressing pMLG57; track 2: E. coli containing pUC18. The positions of protein molecular weight markers are indicated in $\mathrm{kDa}$ 


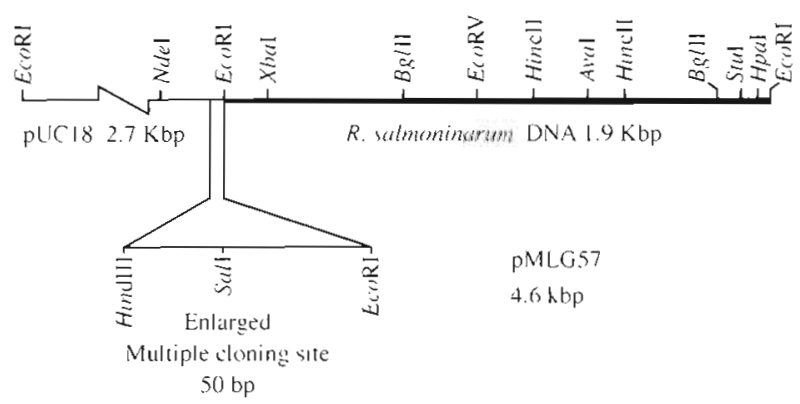

Fig. 2. Restriction map of pMLG57 containing the fragment of Renibacterium salmoninarum DNA from which the portion of gene msa to be fused was excised

degradation of the fusion protein regardless of the growth temperature and despite the care taken to carry out the purification of the fusion proteins as quickly as possible and at $4^{\circ} \mathrm{C}$. Only a small proportion of each of the fusion proteins was found to possess the expected molecular weights of 90313 (pMP57SX) or 92495 (pMP57HS). One possible explanation for this is that the
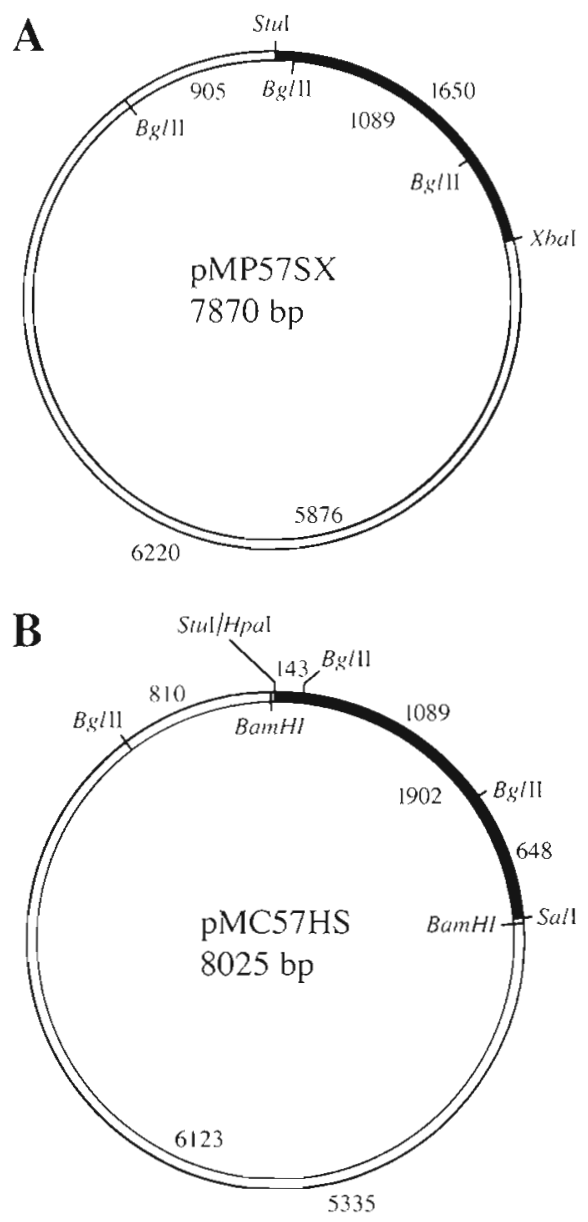

Fig. 3. Physical maps deduced for (A) pMP57SX and (B) pMC57HS. Numbers represent base pairs between neighboring restriction sites
MBP-p57 fusion protein undergoes some form of autoproteolytic processing. Studies of native p57 derived from in vitro cultures of Renibacterium salmoninarum have shown that the p57 protein does possess an inherent instability (Griffiths \& Lynch 1991) although this has been associated with the presence of a serine protease of molecular mass about $105 \mathrm{kDa}$ by other workers (Rockey et al. 1991). Further examination of the amino acid sequence for p57 which was derived from msa (Chien et al. 1992) revealed the presence of a consensus serine protease motif, G-X-S-X-G, located from Gly-406 to Gly-410 (GTSIG) with Asp-323 and His-279 completing the active site (Aitken 1990). Nevertheless, the MBP-p57 fusion protein still contained major epitopes which were recognised on Western blots by rabbit antiR. salmoninarum ECP (data not shown) and the soluble fusion protein was therefore considered to be of use for further immunological study. In order to obtain a maximum yield, MBP-p57 fusion protein was purified from the cytoplasm of $E$. coli XL1-Blue containing pMC57HS by the one-step affinity chromatography procedure. In this case, p57 was fused to MBP starting from Asn-45 which is 18 amino acids downstream from the $\mathrm{N}$-terminal serine that is exposed following cleavage of the signal peptide (Chien et al. 1992).

Western blots showed that specific antibodies raised in rat identified the affinity purified MBP-p57 as a full length fusion protein of estimated molecular mass $90 \mathrm{kDa}$ with the largest proportion of the protein degraded to 55000 or less (Fig. 4). Western blots of Renibacterium salmoninarum cell extracts and ECP which were probed with antiserum to MBP-p57 recognised a series of bands which correspond to the profile of breakdown products of native p57 that have been described by previous researchers (Griffiths \& Lynch 1991, Rockey et al. 1991). R. salmoninarum does not utilize starch or maltose and Western blots of cell extracts or ECPs which had been probed with rabbit anti-MBP showed no evi-

Fig. 4. Immunological detection of affinity purified MBP-p57 fusion protein by Western blot probed with rat anti-MBP-p57. The positions of protein molecular weight standards are marked in $\mathrm{kDa}$. The position of the full length fusion protein is arrowed. The remaining bands represent breakdown products of MBP-p57

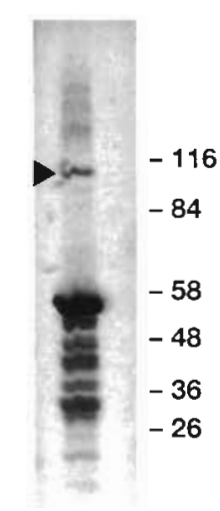


dence for the recognition of any cross reactive epitopes. Major epitopes were present in all strains of $R$. salmoninarum of molecular masses about 58,45 and, to a lesser extent, $35 \mathrm{kDa}$ in sonicated $R$. salmoninarum cell extracts regardless of the availability of iron (Fig. 5A, B). The ECPs derived from iron-sufficient cultures possessed major bands which were recognised by the antiserum at $25 \mathrm{kDa}$ and only strains ATCC 33209 and 910019 were exceptions with a band located at about $57 \mathrm{kDa}$ (Fig. 5C, D). However, ECPs derived from iron-restricted cultures showed a dramatic reduction in the degradation and production of the major epitopes located at $57 \mathrm{kDa}$, particularly in strains MT417, MT420 and MT452. Current understanding of the molecular genetics of $R$. salmoninarum is insufficient to account for this finding but it is possible that iron is involved either directly or indirectly in the regulation of the processing of p57. Interestingly, epitopes of MBP-p57 were detected in R. salmoninarum strains MT414 and MT417 which have previously been shown to be non-autoagglutinating and non-hydrophobic and were described as lacking a $57 \mathrm{kDa}$ saline extractable cell-associated protein that has been associated with virulence (Bruno 1988, 1990). Nevertheless, this study has shown that these strains possess epitopes, both in cell extracts and ECPs, which are recognised by MBP-p57 antiserum. This finding raises the possibility that the hydrophobicity of $R$. salmoninarum may be related to aspects of the cell surface other than simply the presence of p57. Indeed, computer analysis of the published amino acid sequence (Chien et al. 1992) using DNAStar software predicts $p 57$ to be a predominantly hydrophilic molecule (data not shown).

The availability of the cloned msa sequence which encodes a product that possesses the major epitopes of p57 will greatly simplify any future work, such as sitedirected mutagenesis, aimed at characterising the precise role of individual amino acid residues in the biochemical and immunological properties of the protein.

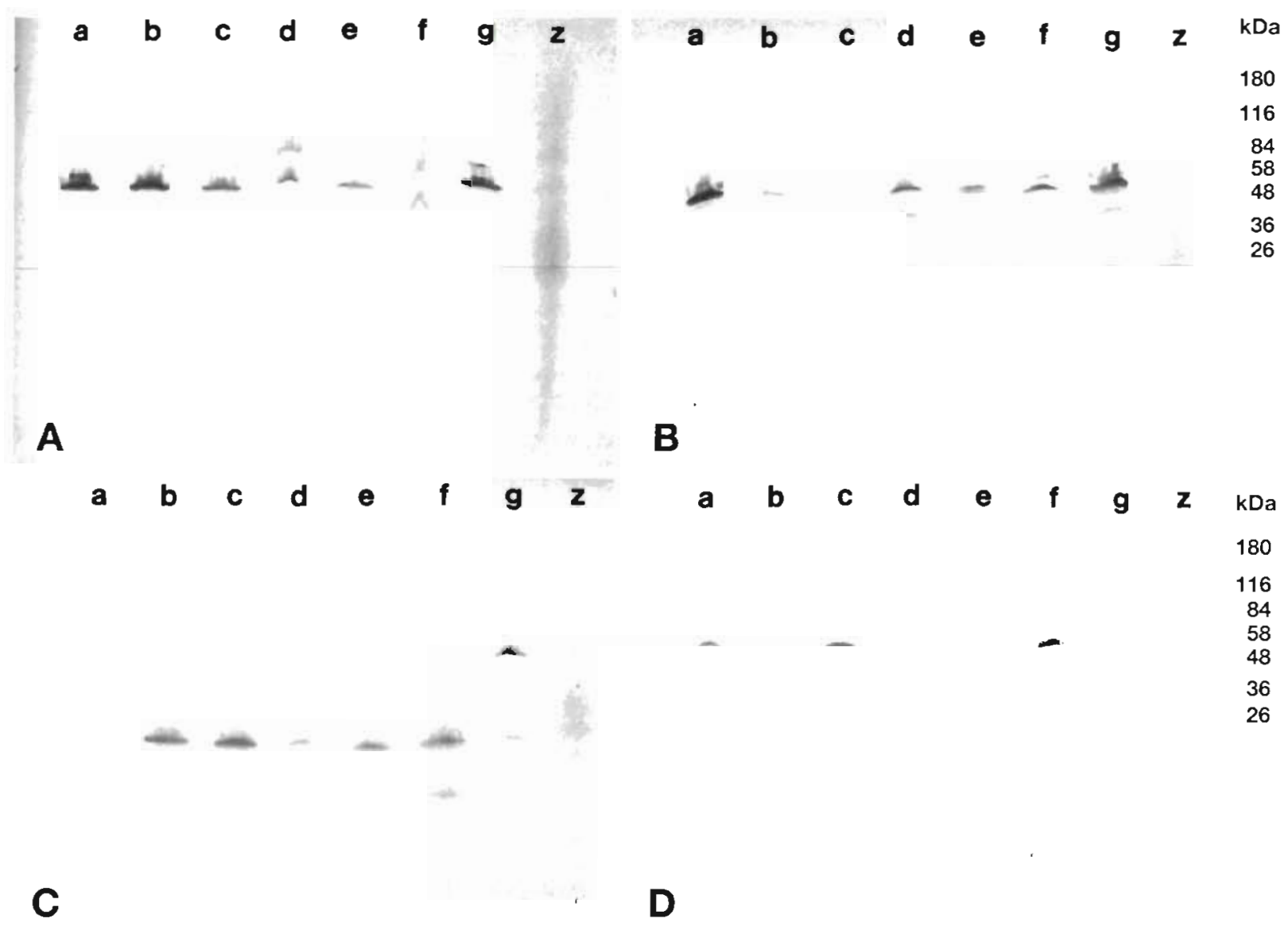

Fig. 5. The immunological detection of epitopes of affinity purified MBP-P57 in cell extracts and ECPs of 7 Renibacterium salmoninarum strains which had been cultured under conditions of either iron restriction or 1 ron sufficiency. Western blots were probed with rat anti-MBP-p57. (A) and (B) are whole cell extracts of cultures grown in either MHCB or MHCB supplemented with $200 \mu M$ EDDHA, respectively. (C) and (D) are ECPs derived from cultures grown in either MHCB or MHCB supplemented with $200 \mu \mathrm{M}$ EDDHA, respectively, Tracks: (a) strain 910019; (b) strain MT452; (c) strain MT425; (d) strain MT420; (e) strain MT417; (f) strain MT414; $(\mathrm{g})$ strain ATCC 33209 . The positions of protein molecular welght standards are indicated in $\mathrm{kDa}$ 
Acknowledgements. This work was supported by a grant from the Scottish Salmon Growers Association Ltd. We thank SOAFD Marine Laboratory, Aberdeen, Scotland, for bacterial strains, helpful advice and assistance, and Drs A. B. Wrathmell and P. J. Glynn for assistance

\section{LITERATURE CITED}

Aitken A (1990) Identification of protein concensus sequences: active site motifs, phosphorylation, and other post-translational modifications. Ellis Horwood, London

Bradford M (1976) A rapid and sensitive method for the quantitation of microgram quantities of protein utilising the principle of protein-dye binding. Analyt Biochem 72 : $248-254$

Bruno DW (1988) The relationship between auto-agglutination, cell surface hydrophobicity and virulence of the fish pathogen Renibacterium salmoninarum. FEMS Microbiol Lett 51:135-140

Bruno DW (1990) Presence of saline extractable protein associated with virulent strains of the fish pathogen Renibacterium salmoninarum. Bull Eur Ass Fish Pathol 10:8-10

Chien MS, Gilbert TL, Huang C, Landolt ML, O'Hara PJ, Winton JR (1992) Molecular cloning and sequence analysis of the gene coding for the $57-\mathrm{kDa}$ major soluble antigen of the salmonid fish pathogen Renibacterium salmoninarum. FEMS Microbiol Lett 96:259-266

Daly JG, Stevenson RMW (1987) Hydrophobic and haemagglutinating properties of Renibacterium salmoninarum. J gen Microbiol 133:3575-3580

Dubreuil JD, Jacques M, Graham L, Lallier R (1990) Purifica-

Responsible Subject Editor: T. Evelyn, Nanaimo, B.C., Canada tion, and biochemical and structural characterization of a fimbrial haemagglutinin of Renibacterium salmoninarum. J gen Microbiol 136:2443-2448

Evelyn TPT (1993) Bacterial kidney disease-BKD. In: Inglis V, Roberts RJ, Bromage NR (ed) Bacterial diseases of fish Blackwell, Oxford, p 177-195

Evenden AJ, Grayson TH, Gilpin ML, Munn CB (1993) Renibactenum salmoninarum and bacterial kidney diseasethe unfinished jigsaw. A Rev Fish Dis 3:87-104

Grayson TH, Bruno DW, Evenden AJ, Gilpin ML, Munn CB (1995) Iron acquisition by Renibacterium salmoninarum: contribution of iron reductase. Dis aquat Org 22:157-162

Griffiths SG, Lynch WH (1991) Instability of the major soluble antigen produced by Renibacterium salmoninarum. J Fish Dis 14:55-66

Laemmli UK (1970) Cleavage of structural proteins during assembly of the head of bacteriophage T4. Nature 222: $680-685$

Rockey DD, Turaga PSD, Wiens GD, Cook BA, Kaattari SL (1991) Serine proteinase of Renibacterium salmoninarum digests a major autologous extracellular and cell-surface protein. Can J Microbiol 37:758-763

Towbin H, Staehelin T, Gordon J (1979) Electrophoretic transfer of proteins from polyacrylamide gels to nitrocellulose sheets: procedure and some applications. Proc Natl Acad Sci USA 76:4350-4354

Turaga P, Wiens G, Kaattari S (1987) Bacterial kidney disease: the potential role of soluble protein antigen(s). J Fish Biol 31(Suppl A):191-194

Wiens GD, Kaattari SL (1991) Monoclonal antibody characterization of a leukoagglutinin produced by Renibacterium salmoninarum. Infect Immun 59:631-637

Manuscript first received: September 13,1994

Revised version accepted: March 14, 1995 